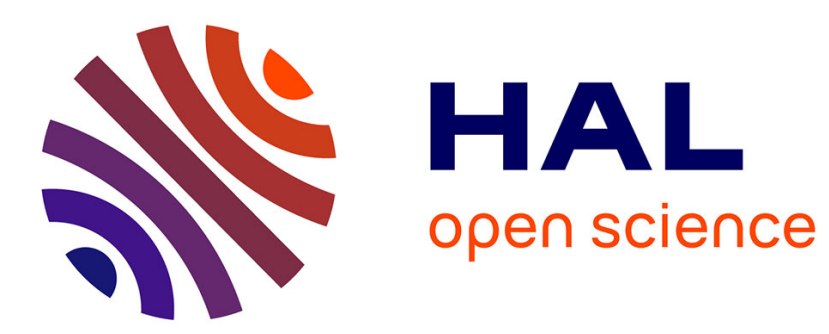

\title{
Forest Monitoring Using Remote Sensing Data and ILWIS GIS
}

\author{
Polina Lemenkova
}

\section{To cite this version:}

Polina Lemenkova. Forest Monitoring Using Remote Sensing Data and ILWIS GIS. Recent Research Directions in the XXI Century: Theory and Practice, Voronezh State University of Forestry and Technologies n. a. G. Morozov VGLTU, Dec 2015, Voronezh, Russia. pp.346-350, 10.6084/m9.figshare.7210364 . hal-01974737

\section{HAL Id: hal-01974737 https://hal.science/hal-01974737}

Submitted on 11 Jan 2019

HAL is a multi-disciplinary open access archive for the deposit and dissemination of scientific research documents, whether they are published or not. The documents may come from teaching and research institutions in France or abroad, or from public or private research centers.
L'archive ouverte pluridisciplinaire HAL, est destinée au dépôt et à la diffusion de documents scientifiques de niveau recherche, publiés ou non, émanant des établissements d'enseignement et de recherche français ou étrangers, des laboratoires publics ou privés.

\section{(c)(2)}

Distributed under a Creative Commons CCO - Public Domain Dedication| 4.0 International 
УДК 528.9

\section{МОНИТОРИНГ СОВРЕМЕННОГО СОСТОЯНИЯ ЛЕСОВ ПО МАТЕРИАЛАМ ДИСТАНЦИОННОГО ЗОНДИРОВАНИЯ И ILWIS ГИС FOREST MONITORING USING REMOTE SENSING DATA AND ILWIS GIS}

Леменкова П.А., аспирант, Карлов университет, Институт экологических исследований г. Прага, Чехия

DOI: 10.12737/16504

Аннотация: Работа оценивает изменения в типах растительного покрова российского Севера в течение последних двух десятилетий. Результаты проведенной классификации спутниковых снимкой показывают экологические аспекты изменения лесотундровых экосистем. Технически, обработка данных была выполнена в ПО ГИС ILWIS, с использованием методов дешифрирования и контролируемой классификации. Результаты позволяют выявить изменения в типах и распределении растительного покрова.

Summary: This paper focuses on the assessment of the changes in land cover types in Yamal peninsula over the past two decades, which shows local environmental aspects of the climate change in North. Technically, the data processing was performed in ILWIS GIS, using semi-automated methods of image interpretation and supervised classification. The results of the classification analysis enable to identify changes in land cover types and their distribution in Yamal.

Keywords: ГИС, растительный покров, спутниковые снимки Ключевые слова: GIS, Vegetation Cover, Remote Sensing Data

Changes in the land cover types in the Russian North are caused by various reasons. These include multiple ecological and social factors, such as permafrost degradation, reindeer grazing and gas-field development, as well as overall climate and environmental changes [6]. The research area is geographically located on the northwestern part of Yamal, West Siberia. The physical-geographical setting of the research area naturally defines its environmental conditions. Geomorphology of Yamal is flat homogeneous land with maximal elevations lower than $90 \mathrm{~m} \mathrm{[6].} \mathrm{The} \mathrm{lowland}$ region creates ideal conditions for the world's largest contiguous high-latitude wetland system, which covers in total $900,000 \mathrm{~km}^{2}$ of peatlands [4]. 
Several approaches of supervised classification have been described previously [2], [3]. They report various methods of image classification, from which the most well-known are Maximum Likelihood Classifier and Nearest Distance Classifier. The Maximum Likelihood Classifier is one of the most used, due to its easy and intuitive logical methodology, ease of application and simplicity [1]. Besides, the Maximum Likelihood Classifier enables to receive the most homogenous classes in the classification results, comparing to other methods [5]. The research methods used in this work consist in application of the remote sensing and GIS tools for land cover studies. These include supervised classification, performed through the identification of land cover types, based on spectral reflectance properties of the pixel DNs, visually interpreted on the Landsat scenes. The ILWIS GIS, open source software, provides tools for satellite imagery processing, spatial analysis and GIS mapping.

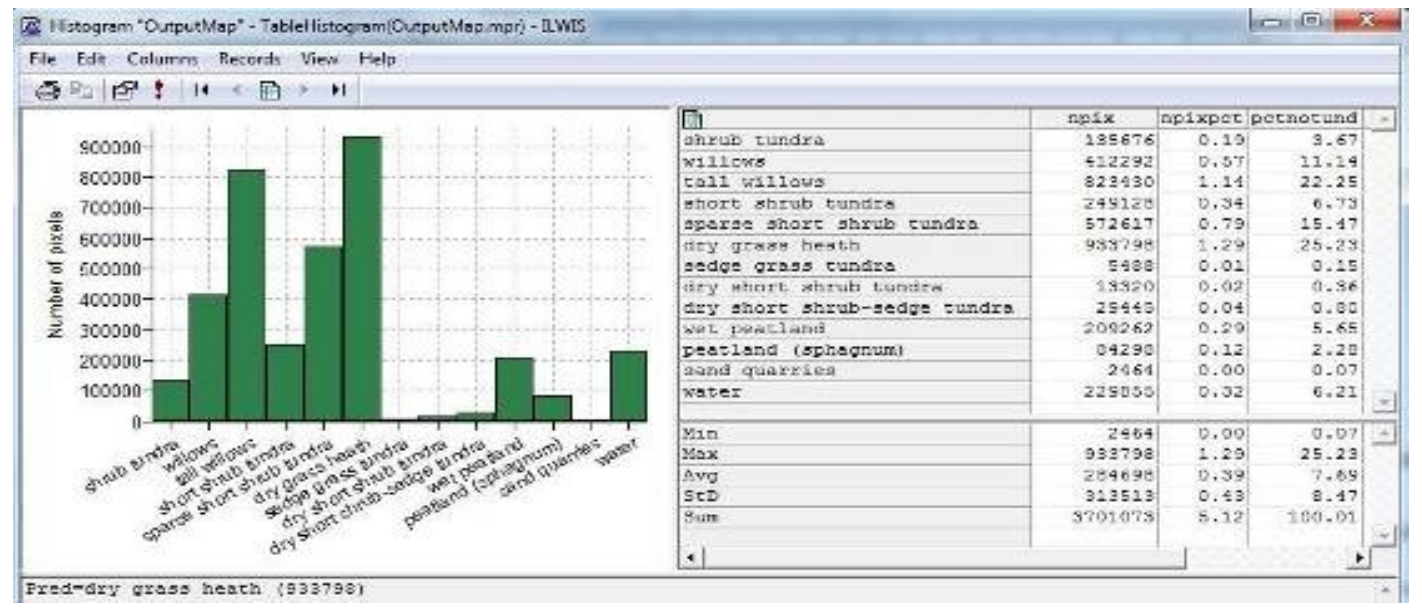

Fig.1 - Histogram for supervised classification of the AOI, Landsat TM, 1988

According to these classes, the training pixels, which belong to each class and have similar spectral values, were selected as representative examples for each of these land cover classes, respectively. The supervised classification of the multispectral imagery has been performed using "classify" operator applied on three Landsat scenes: Landsat TM, 1988, TM, 2011, and Landsat ETM+, 2001. The classification process included following steps. First, the models of the classes were defined by creating a "sample set" in ILWIS menu. In the sample set we created classes, each of them represents land cover and vegetation classes, presented in the research area. These are the following ones: 1) shrub tundra, 2) willows, 3) tall willows, 4) short shrub tundra, 5) sparse short shrub tundra, 6) dry grass heath, 7) sedge grass tundra, 8) dry short shrub tundra, 9) dry short shrub-sedge tundra, 10) wet peatland, 11) peatland (sphagnum). 


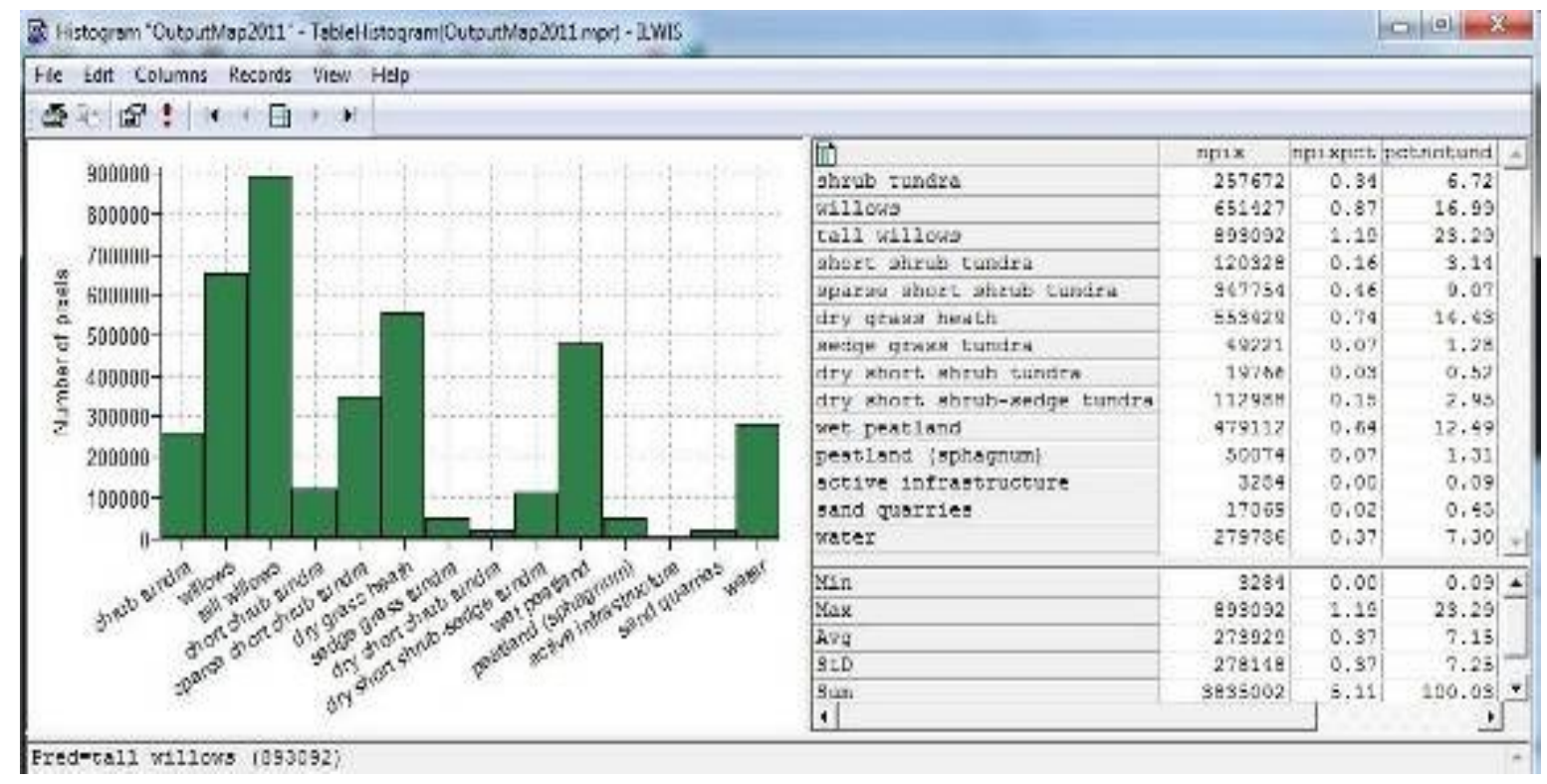

Fig.2 - Histogram for supervised classification of the AOI, Landsat TM, 2011

Also separated classes were created for 12) active infrastructure (buildings and main road network), as well as for 13) sand quarries, 14) water (separated subclasses for lakes and ocean). In totally, 14 classes were defined. These pixels have contrasting colors, visually visible and distinguishable on the image, and therefore serve as training areas for all these classes, mentioned above. A created Sample Set has a reference to the set of Landsat bands (1-7), which are needed to create sample statistics. After assigning pixel sets, a raster polygon map was automatically created. It contained sample pixels, their location and legend, i.e. names of the classes allocated to pixels.

Easy interpretation of the image strongly depends on the optimal color composite map. Therefore, to choose proper combination of bands we used interactive color composite using "Map List as Color Composite" function in ILWIS menu, which enabled to interactively configure combination of bands and to change various images in order to achieve the optimal visualization of the color composite. The combinations of RGB menu and HSI (Hue, Saturation and Intensity bands) and YMC (Yellow, Magenta, and Cyan) were also tried out. Finally, the band combination of 5-2-1 was accepted. The second step consisted of actual supervised classification. During the research work Landsat imagery has proved to be useful spatial resource for land cover studies in the North. Current research was made using ILWIS GIS spatial analysis tools and supervised classification of Landsat satellite scenes. 


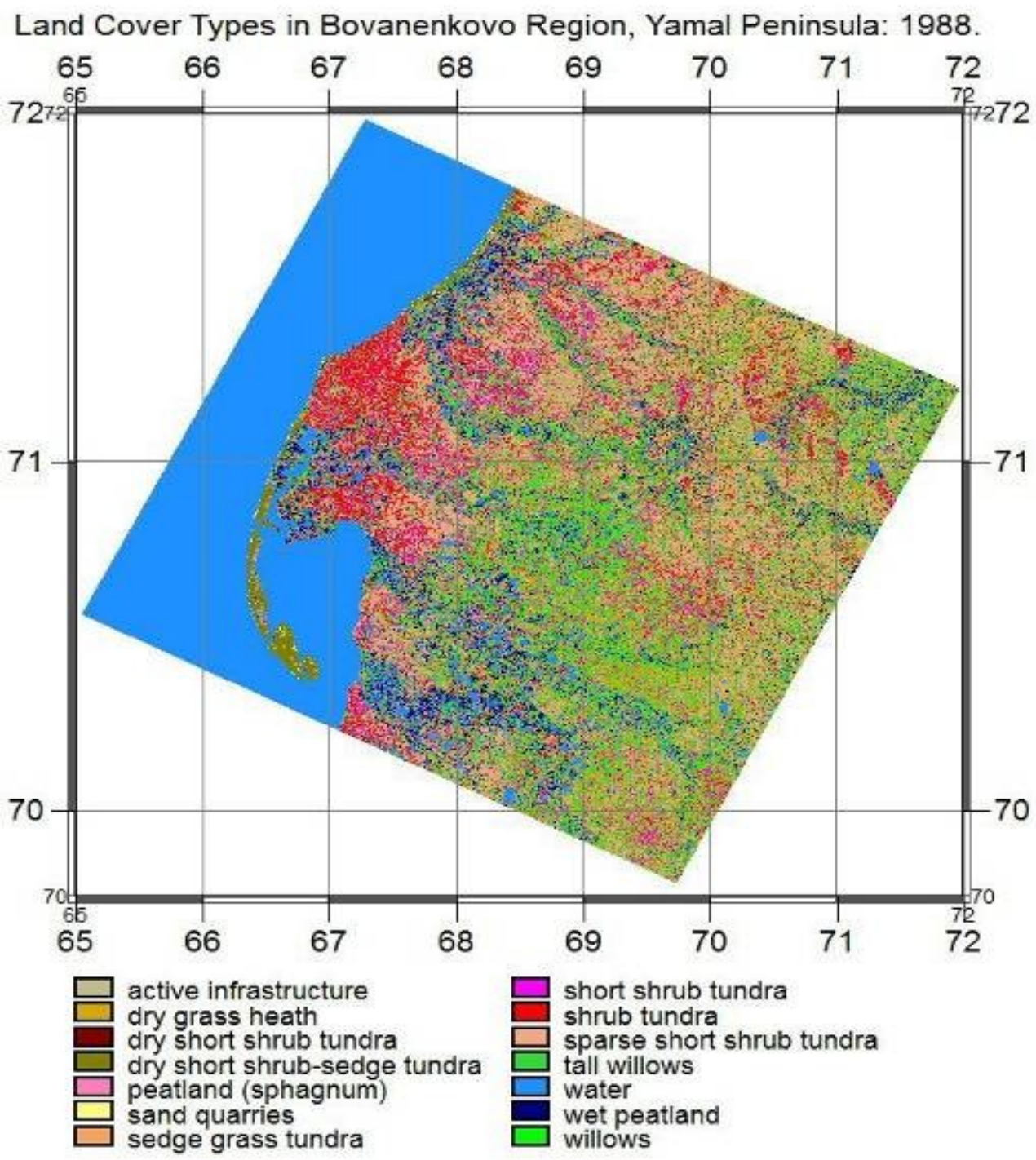

Fig.3 - Landsat TM based classified image: land cover classes, Yamal, 1988.

Detected variations in land cover types can indicate environmental changes in the northern landscapes in Yamal Peninsula.

\section{Список литературы}

1. Du, P., Li, X., Cao, W., Luo, Y., and Zhang, H., 2010a. Monitoring urban land cover and vegetation change by multi-temporal remote sensing information. Mining Science and Technology, 20, 0922-0932.

2. Du, H., Cui, R., Zhou, G., Shi, Y., Xu, X., Fan, W., and Lu, Y., 2010b. The responses of Moso bamboo (Phyllostachys heterocycla var. pubescens) forest aboveground biomass to Landsat TM spectral reflectance and NDVI. Acta Ecologica Sinica, 30, 257-263. 
3. Julien, Y., Sobrino, J.A., and Jimenez-Munoz, J.-C., 2011. Land use classification from multitemporal Landsat imagery using the Yearly Land Cover Dynamics (YLCD) method. International Journal of Applied Earth Observation and Geoinformation, 13, 711-720.

4. Kremenetski, K.V., Velichko, A.A., Borisova, O.K., MacDonald, G.M., Smith, L.C., Frey, K.E., Orlova, L.A., 2003. Peatlands of the Western Siberian lowlands: current knowledge on zonation, carbon content and Late Quaternary history. Quaternary Science Reviews, 22, 703-723.

5. Virtanen, T., Mikkola, K., Patova, E., and Nikula, A., 2002. Satellite image analysis of human caused changes in the tundra vegetation around the city of Vorkuta, north-European Russia. Environmental Pollution, 120, 647-658.

6. Walker D.A., Leibman M.O., Epstein H.E., Forbes B.C., Bhatt U.S., Raynolds M.K., Comiso J.C., Gubarkov A.A., Khomutov A.V., Jia. G.J., Kaarlejärvi E., Kaplan J.O., Kumpula T., Kuss P., Matyshak G., Moskalenko N.G., Orekhov P., Romanovsky V.E., Ukraintseva N.G., and Yi Q., (2009), Spatial and temporal patterns of greenness on the Yamal Peninsula, Russia: interactions of ecological and social factors affecting the Arctic normalized difference vegetation index. Environmental Research Letters 4, 045004 (16).

УДК 674.8

ОСОБЕННОСТИ ОПРЕДЕЛЕНИЯ ГЛАВНОГО КРИТЕРИЯ

КАЧЕСТВА В ТЕХНОЛОГИЧЕСКОМ ПРОЦЕССЕ

ДЕРЕВООБРАБОТКИ

THE FEATURES OF DEFINITION OF THE MAIN QUALITY CRITERION IN THE PROCESS OF WOODWORKING

Львович И.Я., д.т.н., профессор, Панъевропейский университет г.Братислава, Словакия Преображенский А. П., к.ф.-м.н., доцент, Чопоров О.Н., д.т.Н., профессор АНОО ВО Воронежский институт высоких технологий г.Воронеж, Россия, DOI: 10.12737/16506

Аннотация: в работе рассматриваются задачи, связанные с оптимальным выбором управляемых параметров технологических систем деревообработки. 